\title{
SOBRE O RACISMO QUE SOBROU
}

\author{
Fernanda Oliveira Domingos
}

Graduada em Direito pela Universidade Federal da Bahia (UFBA).

Deitado sob os pés dos portões da Praça Piedade

Piedade de mim ninguém tem

E quem passa só vê maldade

Resquícios de um etnocentrismo

De um catolicismo que me silenciou

Por uma pele escura que alguém de lá profanou

Racismo, seletivismo

É tudo parte do mesmo colonialismo

Hoje encarcerado

quem outrora foi escravizado

É só outra face do mesmo descarte

Expurgar o diferente

Por cor ou por sua cultura latente

E ainda ousam subjugar a gente

Dizendo que pra lá é que é país pra frente. 